\title{
The Politics of Poverty in Contemporary Russia
}

\author{
Ann-Mari Sätre \\ New York: Routledge 2019 \\ 184 sider. ISBN 9780815347323
}

Omtalt av Kirsti Stuvøy [ph.d., førsteamanuensis ved Noragric, Norges miljø- og biovitenskapelige universitet (NMBU), kirsti.stuvoy@nmbu.no]

I vurderinger av hvor Russland er på vei har fattigdom fått langt mindre oppmerksomhet enn rike oligarker og deres politiske makt. Russlands post-sovjetiske utvikling var i 1990-tallets kriseår preget av fattigdom på grunn av sjokk-privatisering og politisk kaos. Men velstandsøkningen på 2000-tallet endret bildet, og president Vladimir Putin vokste for mange fram som en redningsmann. Men etter år med bedre økonomiske tider, høyere konsum, hyppige utenlandsreiser og andre fordeler av å være integrert i den globale kapitalismen i det 21 . århundre, er det igjen krise i Russland. Også denne gang har den utviklet seg parallelt med et endret geopolitisk bilde, anført av vestlige lands sanksjoner mot Russland etter annekteringen av Krim i 2014. I denne situasjonen er fattigdom et samfunnsproblem i Russland det er god grunn til å se nærmere på.

I boka "The politics of poverty in contemporary Russia» undersøker Ann-Mari Sätre hva som kjennetegner fattigdom i Russland i dag. En motivasjon for undersøkelsen er den økende ulikheten i landet og det betydelige omfanget på fattigdomsproblemet: en tredel av befolkningen i Russland antas å være fattig. For å kunne beskrive fattigdomsproblemet har Sätre kombinert ulike typer kilder i tillegg til offisiell tilgjengelig statistikk. Med surveys over en lengre tidsperiode og intervjuer av eksperter på sosiale spørsmål i kommuneadministrasjoner, på barnehjem, skoler og internat samt med vanlige folk, utfyller Sätre mangelfull statistisk data. I boka brukes de kvalitative kildene gjennomgående til å illustrere og gi innsikt i ulike aspekter ved fattigdomsproblemet i Russland. Den regelmessige bruken av sitater gir leseren et godt innblikk i ulike erfaringer og vurderinger. Siden alle geografiske steder er anonymisert, gir ikke boken noe innsikt i konkrete regioner, selv om boka konkluderer at lokale ressurser, menneskelige og økonomiske, er sentrale for å håndtere fattigdom. Bokas siktemål har vært å vurdere endringer i fattigdommen i dagens Russland, dens konsekvenser og hvordan den er håndtert politisk, av de fattige selv og av deres hjelpere. Slik Sätre beskriver (s. 10) er fokuset på fattigdom valgt som perspektiv på den 
generelle samfunnsutviklingen. Det er et godt valg. Boka gir dyp, empirisk innsikt og tankevekkende grunnlag for videre forskning.

Boka har sju kapitler. Etter en innledende gjennomgang av formål og problemkompleks følger et innblikk i litteraturen på fattigdomsproblematikken i Russland, og ulike forklaringer på fattigdom drøftes. Et kapittel tar for seg statlig politikk på området, før de neste er viet kjønnsdimensjonen i fattigdomsbekjempelsen og hvordan sivilsamfunnet har trådd inn i fraværet eller bortfallet av statlige institusjoner som gir hjelp og støtte. Konklusjonen oppsummerer sentrale karakteristikker ved fattigdomsproblematikken i Russland i dag.

Analytisk retter boka oppmerksomhet mot strukturelle faktorer (institusjoner, regler, orden, normer) og individuell handling (agens). Rammeverket kombinerer institusjons-teoretikeren Douglass North med capability-tilnærmingen til Amartya Sen, som vektlegger grunnleggende menneskelige muligheter. Det teoretiske rammeverket presenteres kort, og det synes ikke å være noen ambisjon å knytte beskrivelsen av fattigdom i Russland til diskusjoner i denne litteraturen. Hensikten er å sette fattigdomsutviklingen i post-sovjetisk Russland i sammenheng med økt fokus på sosialpolitikk utover på 2000-tallet. I dette politikkfeltet har borgerne fått økt oppmerksomhet og oppfordres til å bidra til å løse sosiale spørsmål. Her identifiserer boka en viktig endringsagent samtidig som den understreker at det er nødvendig å analysere institusjonelle faktorer. Jeg kunne ønsket meg mer diskusjon om hvordan rammeverket bidrar til at kildene belyser trekk ved den generelle samfunnsutviklingen i Russland. Her kommer boka til kort.

Empirisk gir boka mye. Fra start av giør Sätre det klart at fattigdom i Russland, som andre steder, er politisk. Grensen for hva det vil si å være fattig er et offentlig definert eksistensminimum, og grensen er bevegelig. Når den senkes, reduseres antallet som har tilgang på offentlige goder. Observasjonen er at mange trenger flere jobber for å opprettholde sin levestandard i dagens Russland. Det gjør mange sårbare på den måten at mindre endringer $\mathrm{i}$ jobbsituasjonen kan føre til at husholdningen blir fattig. I dagens situasjon, der covid-19 har ført til isolasjon, sosial distansering og stillstand i økonomien verden over, er denne sårbarheten en viktig faktor i Russlands utvikling framover. Sätres ambisjon om å rette oppmerksomheten mot systemiske faktorer for fattigdomsproblematikken i Russland gir slik et godt grunnlag for vurderinger om russisk samfunnsutvikling gjennom og etter covid.

Generelt er problemet at mange arbeidstakere har lave lønninger og nesten ikke får det til å gå rundt. Blant sårbare grupper er familier med mange barn i små byer. Spørsmålet er hva de gjør for å håndtere fattigdom. Sätre beskriver at folk gjør mye, men hun ser en tendens til at problemer håndteres i nuet (coping) mer enn at det handles strategisk med sikte på langsiktig endring. Denne tendensen settes i sammenheng med den paternalistiske rollen arbeidsgiver hadde i forholdet til arbeidstaker i sovjet-tida. Arbeidsgiver sørget for bolig, barnehage og andre sosiale ytelser. I dag er de fleste av disse fordelene borte, og folk må betale for transport, telefon, medisiner og annet. Over lang tid har folk redusert sine kostnader og vist høy evne 
til tilpasning til økte utgifter, som er blant de negative effektene av markedsreformer i det post-sovjetiske Russland. Men de er svært sårbare overfor endringer og faren er stor for at de kan havne i en stadig spiral mot det verre.

Den viktigste ressursen folk har for å komme ut av fattigdom, er arbeidskraft. Men å arbeide mer for å få endene til å møtes har sin begrensning. Inntektssystemet er den systemiske faktoren Sätre legger mest vekt på for å forklare fattigdom i Russland. Det er lave inntekter som gjør at folk ikke har råd til å betale for livsopphold. Dette knyttes til en svikt i den post-sovjetiske transformasjonen der jobber i forbrukerindustrien, som i utgangspunktet var ikke-prioriterte i sovjet-systemet, har blitt bevart. Inntektene er deretter: de er lave, mens utgiftene har økt. Dette giør at folk ikke får råd til å betale de økte kostnadene ved livsopphold. For industriansatte, særlig i olje-bransjen og i andre bransjer som jobber med naturressurser, er inntektene langt høyere. Dermed øker også ulikhetene.

En ytterligere systemisk faktor er bostedsregistrering, kjent som propiska på russisk, som knytter formell arbeidstillatelse og tilgang til velferdstjenester til stedet der registreringen er. Mange arbeider ikke på stedet der de er registrert, som også er der de har tilgang til velferdstjenester. Dette, forklarer Sätre, skaper et skille mellom de som er formelt registrert og inkludert og de som, gjennom dette systemet, blir ekskludert. Dette er typisk for sosialt sårbare grupper, som hjemløse, flyktninger og illegale immigranter. Også de som migrerer innad i Russland for å finne jobb kan oppleve å ikke få (midlertidig) registrering. De rammes dermed av dette registreringssystemet, som også er en faktor som opprettholder den uformelle økonomien med uregelmessige og skjulte inntekter.

En bør på mange fattiges skuldre er behovet for å søke og levere dokumentasjon for at man er i nød som grunnlag for å få hjelp. Reint praktisk har byrden på kommunene og deres budsjett økt, og støtten er veldig lav. De politiske reformene har åpnet opp for ikke-statlige aktører på det sosiale feltet og det har utviklet seg et mangfold av lokale aktører, statlige og frivillige, som jobber for å bekjempe fattigdom. Dette vurderer Sätre som positivt fordi det betyr mer oppmerksomhet rettet mot sosialpolitikk i Russland. Feltet er i stor grad basert på frivillighet og er kvinnedominert. I den moderne russiske staten mobiliseres frivilligheten som en patriotisk plikt oppfylt av kvinner samtidig som velferdsgoder bygges ned. Dette har giort sosialhjelp til fattige til et moralsk spørsmål avhengig av lokale forhold.

Med fokus på fattigdomsproblematikken viser Sätre hvordan den russiske staten har fjernet seg fra folks livshverdag og de reelle utfordringer folk har med å skaffe seg et verdig livsopphold. Dette inntrykket har også blitt synlig i Russlands respons på covid-19, som har blitt lagt til regionale og lokale myndigheter. Lokalt finnes initiativ og tiltak som kan hjelpe folk i krise. Strukturelt er problemet at inntektene er for lave, og ved å legge vekt på dette aspektet i den post-sosialistiske politiske økonomien, inviterer Sätre med denne omfangsrike boka til refleksjon og debatt om fattigdomsproblemet i Russland i et bredere, globalt perspektiv. Når denne boka legger vekt på transformasjonsprosessen som forklaringsfaktor, knyttes ikke nedbygging 
av velferdsgoder og overgangen til frivillighet i sosialpolitikken sammen som del av global endring. Underbetalte jobber og behov for flere jobber som strategi for å ha råd til livsopphold er globale fenomen vi kjenner under begrepet prekariat(et). Det kan derfor diskuteres om fattigdomsproblemet i Russland i større eller mindre grad er et resultat av den sovjetiske arven eller av den globale, kapitalistiske normaliteten. Samtidig, spørsmålet om politisk ansvar er viktig, og Sätre setter avslutningsvis fingeren på behovet for økonomisk, sosial og politisk endring i Russland for å gi folk en inntekt de kan leve av. 